The Main Drainage of Towns. By $\mathrm{F}$. Noel Taylor. Pp. xi $+3^{I} 3$; illustrated. London: Charles Griffin and Co. Ltd., I912.) Price I2s. $6 d$. net.

DESPITE the fact that this book is entitled "Main Drainage of Towns," the author has attempted the almost impossible task of dealing, in the course of 295 pages, not only with matters strictly pertaining to main drainage work, but also with questions of house drainage, the theoretical side of sewage disposal sewage disposal works, \&c.

It is therefore scarcely surprising to find that the author has not been successful in his treatment of the whole of the above subjects, particularly as throughout the work there is unmistakable evidence of the lack of that careful revision of the text so essential to the production of a scientific work of value.

In justice to the author, it should be stated that he has collected a great deal of useful information in regard to main drainage work, together with a large number of plans, tables, \&c., which must have entailed considerable labour. On the other hand, the value of the book is very seriously impaired by the careless way in which it is written, the errors in composition being in many cases so serious as to render the meaning of the text obscure.

Careful perusal of the chapters relating to the theory of sewage disposal, sewage disposal works, \&c., clearly indicates that the author would have been well advised to have left this part of the subject alone, especially in view of the various excellent text-books already available on the subject of sewage purification.

The book contains sufficient material for the production of a useful work on the subject of main drainage providing the matter is carefully edited, but as published it certainly cannot be recommended.

E. A.

LETTERS TO THE EDITOR.

[The Editor does not hold himself responsible for opinions expressed by his correspondents. Neither can he undertake to return, or to correspond with the writers of, rejected manuscripts intended for this or any other part of NATURE. No notice is taken of anonymous communications.]

\section{A Tribe of White Eskimos.}

Considerable interest has been aroused by the announcement made by M. Vilhjalmar Stefansson (see Nature of August 22, p. 644), communicated to the Press through Reuter on September 1o, that he had discovered a tribe-or, to be more accurate, thirteen tribes-of white Eskimos living in the neighbourhood of Coronation Gulf and Victoria Island. It is stated that ten of these tribes had never heard of white people-other than themselves. Consequently, it cannot be assumed that this fair complexion is derived from the intercourse, so frequent in recent times, between Eskimos and the men of whaling ships. The telegraphed account states that ${ }^{*}$ M. Stefansson believes the white Eskimos are descendants of the colony which set out from Norway to Greenland some time after the discovery of that island. Ethnologically, the white Eskimos bear not a single trace of the Mongolian type, differing in the shape of the skull and general features, colour NO. 2240 , VOL. 90] of eyes, and texture of hair, which in many cases is red. They spoke Eskimo, though the explorer thought he detected some Norse words. They probably numbered two thousand. Many of them had perfectly blue eyes and blonde eyebrows"

It is, of course, quite possible that a newspaper correspondent may have given a very free rendering of the statements made to him by M. Stefansson. But, in any case, it is important to bear in mind that a description of a race of fair-complexioned Eskimos, living on the shores of Davis Straits, was printed in Europe in 1658 . This account occurs in De Poincy's "Histoire Naturelle \& Morale des lles Antilles de 1'Amerique," which was published at Rotterdam in that year, and contains a chapter (xviii.) incorporating the narrative of Nicolas Tunes, captain of a Flushing vessel, just returned from Davis Straits at the time when De Poincy was occupied with a description of the narwhal-a subject which led him into a long digression on the hunters of the northern narwhal. De Poincy indicates the locality in question in the following terms, here translated from his somewhat archaic French:-"The captain, from whom we have received this narrative, having set out from Zealand at the end of the spring of 1656 , with the intention of discovering some new source of trade in those northern lands, arrived at the end of June in Davis Straits, whence, having entered a river which begins at $64^{\circ}{ }^{\circ} o^{\prime} \mathrm{N}$. lat., he sailed to the seventy-second degree, where the land about to be described is situated."

A very full description is given of the natives, but only the following sentences need be quoted here:"As regards the inhabitants, our travellers report having seen two kinds, who live together on the most friendly terms. Of these, one kind is described as very tall, well-built, of rather fair complexion, and very swift of foot. The others are very much smaller, of an olive complexion, and tolerably well-proportioned, except that their legs are short and thick. The former kind delight in hunting, for which they are suited by their agility and natural disposition. whereas the latter occupy themselves in fishing. A11 of them have very white, compact teeth, black hair, animated eyes, and the features of the face so well made that they presert no notable deformity. Moreover, they are all so vigorous and of such a strong constitution that several of them who have passed their hundredth year are still lively and robust."

In the small, olive-complexioned, short-legged people here described, there is no difficulty in recognising true Eskimos. Those of the tall, comparatively fair type may easily have been the descendants of the Norse colonists, intermingled, it may be, with Eskimos. It is believed by many-for example, by Dr. Nansen ("In Northern Mists," London, 1911, vol. ii., p. 103)-that the early Norsemen in Greenland were not exterminated bv the Eskimos, but were gradually absorbed by them through sucressive intermarriages. Admitting this, it would seem that the fusion of the two races was still only partial in 1656 . Tunes and his comrades speak of black hair as common to both types, but that need not mean much. If black hair was not common among tenthcentury Norsemen, there would have been no distinction in Harald's designation of haar-fager.

However, the point is that an expedition of the year 1656 reported a tall, light-complexioned caste of natives living on the shores of Davis Straits at the same time as others of genuine Eskimo type. It is quite possible that the former, still retaining their individuality. may have migrated westward to Victoria Land. DAvid MacRitchie. 4 Archibald Place, Edinburgh, September 23. 